\title{
Back to Europe
}

\section{ACRL at the 53rd Frankfurt Book Fair}

by Dale Askey and Thea Lindquist

$\mathrm{F}$

or the third year running, American librarians have represented $\mathrm{ACRL}$ at the Frankfurt Book Fair, the world's largest fair for books and electronic media. ${ }^{1}$ At the $53 \mathrm{rd}$ annual fair, which took place October 10-15, 2001, in Frankfurt am Main, Germany, representatives welcomed scores of visitors from around the world to the ACRL exhibit in the International Booksellers' and Librarians' Centre (IBLC).

At this moment in history, when American freedoms are being critically challenged, our presence in Frankfurt as librarians from the world's most open society took on an enhanced sense of importance and relevance.

Sharing our professional spirit and sense of purpose, we invited librarians, vendors, publishers, students, and other visitors from around the world to learn not only about the dynamic environment and mission of U.S. college and research libraries, but also about how free libraries are the bedrock of a democracy.

The fair has a long and proud tradition dating back to the latter 15 th century. First held on the Römerberg, the city's central square, it is not only the largest but also the oldest fair devoted to books in the world. Although overtaken by Leipzig in the mid17 th century as the center of the international book trade, Frankfurt regained its preeminence in the postwar years by reestablishing the fair as we know it in 1949. For more than a half-century, Frankfurt has been the place to display and discover the world's publishing output and the barometer for new trends in the publishing world.

\section{The 53rd Frankfurt Book Fair}

The fair was held on the vast campus of the Frankfurt Convention Center or Messegelände. Its soaring office tower is a familiar landmark in the city skyline. The fair offered a broad view of new paper and electronic publications, as well as current trends in literature, media, science, and scholarship. Altogether, well over 6,500 companies from 105 countries, including almost 2,500 German publishers, showcased their wares at the fair. Nearly 400,000 books were presented during

\section{About the authors}

Dale Askey is reference and Web services librarian at University of Utah, e-mail: daskey@library.utah.edu, and Thea Lindquist is history and Germanic language and literature librarian at University of Colorado at Boulder, e-mail: thea.lindquist@colorado.edu 
the fair, roughly a quarter of which were first editions. Frankfurt is also the world's largest venue for e-publishing, and the trend towards electronic publications at the fair was on the rise.

Despite the September 11 attacks, most American exhibitors attended the event. Repercussions, however, were evident in increased security throughout the convention halls. In addition to the wide range of publisher exhibits, the fair offered everything from cultural and literary exhibits featuring Greece, this year's guest of honor, to various award ceremonies.

German Minister of Culture Julian NidaRümelin, standing in for Chancellor Gerhard Schröder, opened the event with President Constantinos Stephanopoulos and Angelos Delivorrias, Greece's representatives in Frankfurt. During the fair, many events and exhibitions dedicated to presenting and promoting Greek letters abroad were underway. More than 70 Greek publishers and organizations were on hand to present their products in Hall 5, and publishers from other countries offered titles by Greek authors.

Also, the first level of the newly built "Forum" was dedicated to a wide-ranging exhibition illustrating Grecian culture and literature. This forum hosted a series of readings, panel discussions, musical performances, literary workshops, book presentations, and film screenings during the fair. Exhibits with Greek themes were also on display in many of Frankfurt's museums and galleries. ${ }^{2}$

In recognition of the increasingly important role of electronic publications, the Second Annual Frankfurt eBook Awards were given to recognize achievements in the emerging ebook industry. The grand prize in nonfiction was awarded to Steven Levy for Crypto and in fiction to Amitav Ghosh for The Glass Palace. Eminent German philosopher and sociologist Jürgen Habermas was selected as this year's laureate for the Peace Prize of the German Book Trade, which is awarded to an indiviclual who has contributed in an outstanding way to world peace.

\section{The IBLC}

The IBLC creates a space in the center of the Frankfurt Book Fair where librarians, publishers, vendors, and representatives from academic institutions can gather to exchange information and ideas. This year's IBLC boasted diverse representation from organizations and firms, such as Ex Libris, the German library consortium HeBIS, University of Regensbury Library, and the Zentrales Verzeichnis Antiquarischer Bücher, Germany's largest online source for used books.

The ACRL exhibit, strategically located in the IBLC, promoted the publications, services, and benefits of membership in ACRL and the Western European Studies Section (WESS) to colleagues from around the world. During the five-day event, many of the fair's halls were crowded with visitors, particularly on days when it was open to the general public. The IBLC, while located directly adjacent to many of these highly trafficked halls, offered a quieter, yet active, forum for those in the ACRL exhibit to congregate and converse with librarians, vendors, and visitors in the area.

Five American librarians, with generous support from ACRL and the IBLC, were on hand to organize and staff the ACRL exhibit. Gordon Anderson (University of Kansas), Jeffrey Garrett (Northwestern University), and Margot Sutton (ACRL) generously assisted with the pre-fair preparations.

The five official representatives-Dale Askey (University of Utah), Helene Baumann (Duke University), Thea Lindquist (University of Colorado at Boulder), Beth RemakHonnef (University of California-Santa Cruz), and Susanne Roberts (Yale University)—were willingly aided by many of their WESS colleagues at the booth for the duration of the fair. Among them were Roger Brisson (Harvard University), James Burgett (University of Kentucky), Hilde Calvert (Ball State University), Beau David Case (Ohio State University), Diane D'Almeida (Boston University), Denise Hibay (New York Public Library), Gail Hueting (University of Illinois), Mike Olson (Harvard University), Marciá Pankake (University of Minnesota), and Heleni Pedersoli (University of Maryland). All told, there were approximately 25 ACRL members at the fair.

Visitors to the exhibit received a warm welcome from ACRL members eager to discuss American academic librarianship and answer questions. They had the opportunity to peruse issues of ACRL publications, such as Choice, College and Research Libraries, 
CERL News, and titles from ACRL's Publications in Librarianship series, as well as brochures and publications from ACRL sections, including WESS, RBMS, and SEES. Other publications available at the booth included Reference Reviews Europe and Slavic \& East European Information Resources, titles to which many WESS and SEES members contribute. With the assistance of exhibit staff, guests also visited Web sites related to ACRL and American librarianship.

\section{USA Day}

A special feature of this year's IBLC was USA Day, a series of talks by ACRL librarians on aspects of American librarianship given in the IBLC Forum. ${ }^{3}$ Topics included library organization, collaborative collection development, distance learning, bibliographic instruction, and the German Resources Project, an Association of Research Libraries initiative. Colleagues from around the world attended and asked questions that were insightful, instructive, and generated lively discussion among the group on topics of mutual interest.

In the wake of the terrorist attacks in September, it was heartening to receive the support and sympathy of so many international col-

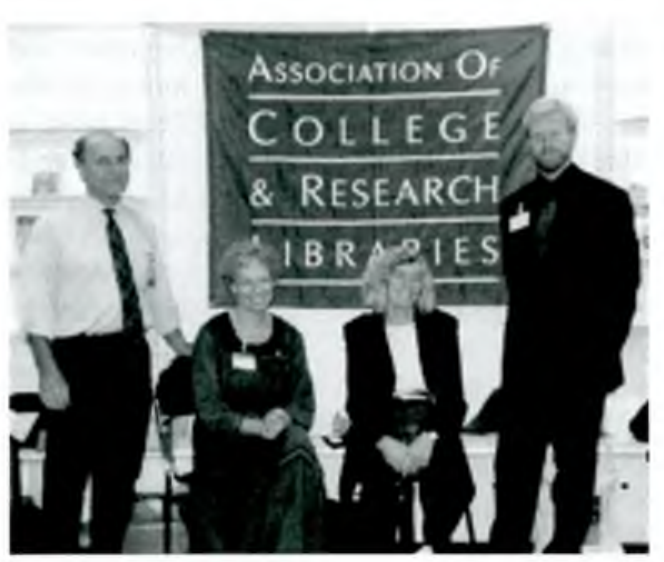

(Left to right): Gordon Anderson (University of Kansas), Helene Baumann (Duke University), Diane D'Almeida (Boston University), and Beau David Case (Ohio State University) at the ACRL booth. journals. Speakers hailed from Germany, the United States, Hong Kong, the Netherlands, and Great Britain. Those from the United States included Andrew Odlyzko (University of Minnesota), Michael Keller (Stanford University), Ann Okerson (Yale University), and Mike Olson (Harvard University). Jeffrey Garrett also moderated the first day of the symposium.

Despite the wide geographic distribution of the speakers, it was eminently clear that in the modern global economy, librarians worldwide face the same issues and pressures from the recent changes in scholarly publishing. The IBLC symposium represented a rare opportunity to bring together experts from many countries to exchange ideas and propose solutions to these problems. As Garrett mentioned in his opening remarks at the symposium, the title contains what could appear to be-at least superficially - a contradiction, namely that competition and cooperation between libraries and commercial services.

As he further pointed out, however, competition and $\mathrm{CO}$ operation are both important aspects of the relationship between academia and industry. Library consortia cooperate with vendors to negotiate price breaks or to start initiatives, such as the Early English Books leagues." On October 11, at the exact time that the World Trade Center was attacked a month earlier, there was a public call for a moment of silence to remember those who lost their lives in New York and Washington, D.C. Once again we were all reminded of how tightly knit and caring the library world is.

\section{IBLC symposium}

The second annual IBLC symposium-_-"Competition and Cooperation: Universities, Libraries, and the Commercial Sector at the Beginning of the 21st Century"-explored various aspects of scholarly communication, such as copyright, licensing, and archiving of online
Online-Text Creation Partnership, while commercial ventures, such as Highwire Press, originate in libraries. Many of the papers presented at the symposium suggested creative ways for libraries and commercial interests to work together productively.

\section{An invaluable experience for international librarians}

As the largest annual gathering of publishers on the globe, the Frankfurt Book Fair provides a unique opportunity for librarians to make contacts with foreign vendors, view publications from numerous nations that do

(continued on page 220) 
the film's impact on popular culture, its place in film history, and an essay on the life and career of director Victor Halperin. This massively documented work will please both academic film historians and horror-genre buffs, and it deserves to be emulated as a model for single-film scholarship in the future. \$65.00. McFarland. ISBN 0-7864-0988-6.

\section{The Women of Afghanistan under the}

Taliban, by Rosemarie Skaine (198 pages, March 2002), was mostly written prior to September 2001, though the author and publisher masterfully managed to squeeze in a few last-minute references to the United States counterattack and the Taliban's thenuncertain future. Skaine catalogs the hardships and atrocities imposed by the regime on Afghan women, 30 of whom were interviewed in 2000 after they had fled the coun- try. The final chapter summarizes the political and diplomatic efforts made by organizations and individuals in other countries to rebuild Afghan society and women's roles within it. \$29.95. McFarland. ISBN 0-7864-1090-6.

World War II in American Art, by Robert Henkes (157 pages, December 2001), analyzes the works of artists who experienced the intensity and emotion of the war firsthand, both in battle and on the homefront. Arranged by subject matter, the book includes sections on combat, the wounded, survivors, prisoners, ruins, the dead, religion, recreation, and victory. Many of the paintings depicted are housed in the collections of the Army, Navy, and Air Force museums, as well as the personal collection of artist Edward Reep, who wrote the foreword. \$39.95. McFarland. ISBN 0-78640985-1.
("Back to Europe" continued from page 206)

not market to the United States, and see new products and services from around the world.

To the first-time visitor, the fair may be simply overwhelming with its thousands of exhibitors and activities. The more seasoned veterans in the ACRL group did an excellent job of showing the neophytes how to make their time in Frankfurt productive.

The book fair also marks the highlight of the publishing year in Germany, and many publishers release major titles in conjunction with this annual event. German, Austrian, and Swiss newspapers typically publish literary supplements that review the cream of the crop. Many librarians collect these supplements and peruse them for well-reviewed titles to add to their collections.

Mike Olson accomplished the Herculean task of gathering 22 of these supplements from newspapers large and small, culling 325 titles from them, and compiling these titles into a bibliography, the first volume in a series. His bibliography is an invaluable tool for anyone who wants to know what is hot this year.

Many of the ACRL librarians have bibliographic responsibilities beyond Germany and Western Europe. By walking through the halls devoted to Central and Eastern Europe, Africa, Asia, and Latin and South America, one can quickly assemble a long list of titles that may otherwise have been impossible to identify through standard sources.

Whether one needs to know about current titles from Armenia or wants to find a good source for reference works from Argentina, Frankfurt is the place to be.

\section{Notes}

1. Details and information on the Frankfurt Book Fair are available at http:// warw.frankfurt-book-fair.com.

2. Background information on Greece as guest of honor may be found at http:// WWW.greece.gr/CULTURE/Literature/ greeceinfrankfurt.stm.

3. "IBLC meets ... Representatives of American Libraries: Vorträge und Veranstaltungen im IBLC-Forum." For a list of the talks, see http://www.stub.unifrankfurt.de/messe/meets.htm.

4. It should not be forgotten that many Europeans were also victims of the World Trade Center tragedy.

5. Michael P. Olson, New Books from Germany, Austria, and Switzerland: A Bibliography on the Occasion of the 53rd Frankfurt Book Fair, 10-15 October 2001, Harvard College Library Series in Germanic Bibliographies, vol. 1 (Cambridge, Mass.: Harvard College Library, 2001). 